\title{
SUPLEMENTASI KEMBANG TELANG (Clitoria ternatea) UNTUK PENINGKATKAN KUALITAS SILASE BATANG PISANG
}

\author{
I W. Suarna, I M. Mudita, I W. Wirawan, dan N. N. Suryani \\ Puslitbang Tumbuhan Pakan, LPPM Universitas Udayana \\ e-mail: wynsuarna@unud.ac.id
}

\begin{abstract}
ABSTRAK
Penyediaan pakan berkesinambungan dan berkualitas sangat penting untuk meningkatkan produktivitas ternak. Batang pisang yang tersedia melimpah dan murah dapat ditingkatkan daya gunanya sebagai sumber pakan berkualitas melalui teknologi silase dengan penambahan hijauan Clitoria ternatea. Penelitian ini mengkombinasikan batang pisang dengan hijauan C. ternatea dibuat dalam bentuk selase complete feed melalui penambahan pollar, molasis dan EM4 ke dalam empat perlakuan. Kontrol (perlakuan A): $65 \%$ batang pisang $+30 \%$ pollar $+5 \%$ (molasis + EM4); perlakuan B: $55 \%$ batang pisang $+10 \%$ C. ternatea $+30 \%$ pollar $+5 \%$ (molasis + EM4); perlakuan C: $45 \%$ batang pisang $+20 \%$ C. ternatea $+30 \%$ pollar + $5 \%$ (molasis + EM4); dan perlakuan D: $35 \%$ batang pisang $+30 \%$ C. ternatea $+30 \%$ pollar $+5 \%$ (molasis + EM4). Masing-masing perlakuan terdiri atas tiga ulangan. Penelitian dilaksanakan untuk mendapatkan kombinasi silase batang pisang dan hijauan C. ternatea yang terbaik melalui pengamatan kualitas fisik, sifat pisik, kandungan nutrien dan kecernaan secara in vitro. Data yang diperoleh dianalisis menggunakan Anova. Hasil penelitian menunjukkan terjadi peningkatan kandungan nutrisi, kecernaan bahan kering dan bahan organik serta penurunan komponen penghambat kecernaan secara in vitro. Kesimpulan penelitian ini adalah, penambahan $C$. ternatea dalam silase batang pisang sampai 30\% menghasilkan kandungan bahan organik, protein kasar, energi, kecernaan bahan kering dan bahan organik tertinggi dan kandungan serat kasar terendah.
\end{abstract}

Kata kunci: silase, batang pisang, Clitoria ternatea, in-vitro

\section{SUPLEMENTATION OF KEMBANG TELANG (Clitoria ternatea) FOR IMPROVING THE QUALITY OF BANANA STEMS SILAGE}

\begin{abstract}
Provision of continuous and quality feed is very important to increase livestock productivity. Abundant and inexpensive available banana stems can be improved as a source of quality feed through silage technology with the addition of $C$. ternatea. This study combines banana stems with $C$. ternatea made in the form of complete feed selase by adding pollar, molasis and EM4. There are four treatments i.a. Control (Treatment A): $65 \%$ banana stems $+30 \%$ pollar $+5 \%$ (molasis + EM4); Treatment B: $55 \%$ banana stems $+10 \%$ C. ternatea $+30 \%$ pollar $+5 \%$ (molasis + EM4); Treatment C: $45 \%$ banana stems $+20 \%$ C. ternatea $+30 \%$ pollar + 5\% (molasis + EM4); and Treatment D: 35\% banana stems $+30 \%$ C. ternatea $+30 \%$ pollar + $5 \%$ (molasis + EM4). Each treatment consisted of three replications. The study was conducted to get the best combination of banana stem silage and C. ternatea through observations of physical quality, physical properties, nutrient content and digestibility in vitro. The data obtained were analyzed using Anova. The results showed an increase in nutrient content, digestibility of dry matter and organic matter as well as a decrease in digestive inhibiting components in vitro. The conclusion of this research is, the addition of C. ternatea in silage of banana stems up to $30 \%$ produces organic matter content, crude protein, energy, digestibility of dry matter and the highest organic matter and the lowest crude fiber content.
\end{abstract}

Keywords: silage, banana stems, Clitoria ternatea, in vitro

\section{PENDAHULUAN}

Pakan merupakan faktor penunjang utama keberhasilan dalam suatu usaha peternakan. Pakan ternak ruminansia khususnya kambing, yang berbasis hijauan, ketersediaannya berfluktuasi karena dipengaruhi oleh musim. Dalam usaha menjaga agar ternak tetap bisa berproduksi dengan baik, maka diperlukan strategi pemenuhan pakan dari segi kuantitas, kualitas maupun penyediaan yang 
berkesinambungan. Salah satu solusi mengatasi ketersediaan hijauan pakan ini adalah dengan teknologi pembuatan silase. Beberapa bahan pakan yang sudah dimanfaatkan oleh peternak melalui penerapan teknologi silase, antara lain adalah silase jerami padi, silase kulit kopi, silase limbah sawit dan masih banyak lagi dengan hasil yang cukup memuaskan. Sementara pemanfaatan batang pisang sebagai silase dengan penambahan berbagai akselerator untuk pakan kambing sudah mulai dilakukan dengan hasil yang masih bervariasi.

Indonesia merupakan salah satu dari dua belas negara yang mempunyai luas panen pisang terbesar di dunia. Pada tahun 1980 produktivitas pisang di Indonesia mencapai 12,53 ton/ha kemudian naik pada tahun 2015 menjadi 77,64 ton/ha (Nuryati dan Waryanto, 2016). Total produksi batang pisang dalam berat segar minimum mencapai 100 kali lipat dari produksi buah pisangnya sedangkan total produksi daun pisang dapat mencapai 30 kali lipat dari produksi buah pisang (Wina, 2001).Batang pisang (Musaa spp) merupakan limbah pertanian yang mempunyai potensi sebagai pakan ternak karena belum banyak dimanfaatkan. Batang pisang sebagai pakan ternak mempunyai beberapa kelemahan antara lain: kandungan air yang tinggi dan sebaliknya kandungan nutrisinya rendah. Daya simpan batang pisang sebagai bahan pakan apabila diberikan dalam bentuk segar, tidak bisa bertahan lama dan akan cepat membusuk karena kandungan airnya masih sangat tinggi. Selain itu, kandungan air bahan pakan yang tinggi apabila diberikan pada ternak akan berakibat pada rendahnya intake bahan kering maupun bahan organik sehingga asupan nutisinya juga menjadi rendah. Kelemahan batang pisang bisa diatasi dengan berbagai cara, antara lain dibuat sebagai bahan dasar pembuatan silase dengan penambahan beberapa bahan pakan lain sehingga nilai nutrisinya bisa meningkat dan daya simpan menjadi lebih lama. Batang pisang memiliki kandungan bahan kering (BK) berkisar 3,6-9,8\%; abu 18,4 -24,7\%; protein kasar (PK) 2,4 -8,3\%; serat kasar (SK) 13,4-31, 7\%; lemak kasar 3,2 -8,1\%; neutral detergent fiber 40,6 $-64,1 \%$; acid detergent fiber 35,6-45,5\%; selulosa 19,7-35,2\%; hemiselulosa 4,9-18,7\% dan lignin 1,3-9,2\% (Rochana, 2017). Menurut Wahyono dan Hardianto (2004), pakan ternak yang bersumber dari limbah pertanian dan perkebunan memiliki nilai nutrisi rendah sehingga perlu dioptimalkan kualitasnya melalui teknologi fermentasi dan pembuatan pakan lengkap (complete feed).

Walaupun sudah mulai dilakukan penelitian tentang pemanfaatan silase batang pisang, akan tetapi masih sangat sedikit informasi yang tersedia tentang kandungan nutrisi silase batang pisang dengan tambahan berbagai pakan, pengaruh silase batang pisang terhadap fermentasi rumen maupun pengaruhnya terhadap pertumbuhan maupun produktivitas ternak ruminansia terutama kambing.

Berdasarkan latar belakang di atas, maka penelitian ini dirancang untuk mengkaji kualitas silase batang pisang yang dikombinasikan hijauan kembang telang (Clitoria ternatea/C. ternatea) dan ditambahkan dengan pollard, molasis dan urea serta EM4 pada berbagai level.

\section{MATERI DAN METODE}

\section{Pembuatan Silase}

Batang pisang dipotong-potong $5 \mathrm{~cm}$ kemudian dilayukan 1-2 hari untuk menurunkan kadar airnya. Jika batang pisang sudah berkurang kadar airnya, kira-kira menjadi 70\%, ditambahkan dengan tanaman C. ternatea, pollard, molasis dan EM4 sesuai dengan perlakuan masing-masing. Rancangan yang digunakan adalah rancangan acak lengkap (RAL). Silase terdiri atas 4 (empat) perlakuan dan masingmasing perlakuan diulang tiga kali. Perlakuan tersebut adalah:

A : $65 \%$ batang pisang $+30 \%$ pollar $+5 \%$ (molasis $\left.+\mathrm{EM}_{4}\right)$

B : $55 \%$ batang pisang $+10 \%$ C. ternatea $+30 \%$ pollar $+5 \%$ (molasis $\left.+\mathrm{EM}_{4}\right)$

C : $45 \%$ batang pisang $+20 \%$ C. ternatea $+30 \%$ pollar $+5 \%$ (molasis + EM4)

D : $35 \%$ batang pisang $+30 \%$ C. ternatea $+30 \%$ pollar $+5 \%$ (molasis + EM4)

Bahan silase yang sudah tercampur disimpan dalam kantong plastik dalam keadaan kedap udara. Setelah disimpan selama 21 hari, silase dibuka untuk dilakukan di laboratorium

\section{Analisis Sample di Laboratorium}

Silase yang sudah diamati karakteristik fisiknya, kemudian dikeringkan dan digiling untuk menganalisis komposisi kimianya yang meliputi kandungan: 1) air, 2) bahan kering, 3) bahan organik, 4) protein kasar, 5) serat kasar, 6) abu, dan 7) energi bruto

\section{Prosedur kerja adalah sebagai berikut: Penentuan bahan kering (BK)}

BK sampel ditentukan menggunakan metode Association of Official Analytic Chemist (AOAC, 2005) dengan prosedur sebagai berikut: cawan porselin yang sudah dicuci dan dikeringkan dioven pada temperatur $105^{\circ}-110^{\circ} \mathrm{C}$ selama 3 jam hingga beratnya konstan. Cawan lalu didinginkan dalam desikator selama 30 menit kemudian ditimbang beratnya (W). Cawan diisi $1 \mathrm{~g}$ sampel (S) dioven pada temperatur $105^{\mathrm{O}}-110^{\circ} \mathrm{C}$ selama 9-12 jam, 
setelah itu dinginkan dalam desikator selama 30 menit lalu ditimbang beratnya (WS). BK dihitung dengan rumus:

$$
B K(\%)=\frac{\mathrm{WS}-\mathrm{W}}{\mathrm{S}} \times 100 \%
$$

WS = berat cawan berisi sampel setelah dioven $(\mathrm{g})$

$\mathrm{W}=$ berat konstan cawan kosong $(\mathrm{g})$

$\mathrm{S} \quad=$ berat sampel $(\mathrm{g})$

\section{Penentuan bahan organik (BO)}

BO sampel ditentukan menggunakan metode AOAC (2005) dengan prosedur sebagai berikut: Cawan porselin yang sudah dibersihkan dipanaskan dalam tanur listrik untuk mendapatkan berat konstan pada temperatur $50^{\circ} \mathrm{C}$ selama $3 \mathrm{jam}$, dinginkan selama 30 menit dalam desikator lalu timbang, sehingga diperoleh berat cawan kosong (C). Cawan tadi diisi sampel 1-2 g lalu diabukan pada tanur listrik pada temperatur $500^{\circ} \mathrm{C}$ selama 3-6 jam sampai menjadi warna putih keabu-abuan secara merata. Dinginkan dalam desikator selama 30 menit kemudian ditimbang beratnya (CA).

$$
\text { Kadar } \mathrm{Abu}(\%)=\frac{\mathrm{CA}-\mathrm{C}}{\mathrm{S}} \times 100 \%
$$

Kadar BO $(\%)=100-\mathrm{Abu}(\mathrm{BK})$

Dimana:

$\mathrm{CA}=$ berat cawan $+\mathrm{abu}(\mathrm{g})$

$\mathrm{C}=$ berat konstan cawan kosong

$\mathrm{S}$ = berat sampel yang dimasukkan ke dalam cawan kosong

\section{Penentuan kandungan protein kasar (PK)}

Kandungan protein kasar (PK) ditentukan dengan metode semi mikro "Kjeldahl" yang terdiri dari 3 fase.

1. Fase Destruksi

Sebanyak 0,3 g sampel yang akan dianalisis dimasukkan ke dalam labu "Kjeldahl". Ke dalam labu ditambahkan satu tablet katalis (1 g sodium sulfat anhydrous $+10 \mathrm{mg} \mathrm{Se}$ ), satu butiran gelas dan 5 $\mathrm{ml}_{\mathrm{H}_{2} \mathrm{SO}_{4}}$ pekat. Destruksi dilakukan di dalam ruang asam. Pada awalnya digunakan temperatur rendah, dan setelah asapnya hilang temperatur dinaikkan dan didestruksi sampai jernih. Pemanasan labu dilanjutkan selama 15 menit lagi akan tetapi dijaga agar labu yang berisi sampel tidak sampai kering untuk dilanjutkan ke fase berikutnya.

2. Fase Destilasi

Destilasi dilakukan menggunakan alat destilator ICW (Ivan, Clack, and White). Sampel dalam labu yang telah didestruksi ditambahkan $25 \mathrm{ml} \mathrm{NaOH}$ 50\%. Uap yang keluar dari kondensator ditampung dengan asam borak 2\% yang dicampur dengan indikator campuran (20 ml BCG 0,1\% + $4 \mathrm{ml} \mathrm{MR}$ o,1\% dalam alkohol). Destilasi dihentikan sampai larutan penampung mencapai $50 \mathrm{ml}$.

3.Fase Titrasi

Larutan hasil destilasi kemudian dititrasi dengan $\mathrm{HCl} 0,1 \mathrm{~N}$. Apabila terjadi perubahan warna menjadi merah muda, maka itu merupakan titik akhir fase titrasi.

Kadar Protein Kasar $(\%)=\frac{(\mathrm{a}-\mathrm{b}) \mathrm{x} 0,1 \times 14 \times 6,25}{\text { Berat sampel }(\mathrm{mg})} \times 100 \%$

Keterangan:

$\mathrm{A}=$ volume $\mathrm{HCl}$ untuk titrasi sampel $(\mathrm{ml})$

$\mathrm{B}=$ volume $\mathrm{HCl}$ untuk titrasi blanko $(\mathrm{ml})$

$0,1=$ Normalitas titrator $(\mathrm{HCl})$

$14=$ Equivalen Nitrogen $(\mathrm{mg})$

$6,25=$ faktor protein

\section{Penentuan kadar serat kasar (SK)}

Kadar SK ditentukan dengan menggunakan metode AOAC (2005). Gelas piala ukuran $600 \mathrm{ml}$ diisi 1 g sampel ditambahkan $50 \mathrm{ml} \mathrm{H}_{2} \mathrm{SO}_{4} \mathrm{O}, 3 \mathrm{~N}$ dipanaskan pada penangas pasir hingga mendidih. Setelah 30 menit, tambahkan $25 \mathrm{ml} \mathrm{NaOH} \mathrm{1,5} \mathrm{N}$, dipanaskan kembali selama 30 menit. Setelah itu disaring menggunakan kertas saring bebas abu yang telah diketahui berat konstannya melalui pengopenan $105^{\circ}-110^{\circ} \mathrm{C}$. Penyaringan dilakukan dengan bantuan pompa vakum. Hasil saringan kemudian dicuci berturut-turut dengan $50 \mathrm{ml}$ aquades panas, $50 \mathrm{ml}_{\mathrm{H}_{2} \mathrm{SO}_{4}} \mathrm{O}, 3 \mathrm{~N}, 5 \mathrm{O} \mathrm{ml}$ aquades panas, $25 \mathrm{ml}$ alkohol dan $25 \mathrm{ml}$ aceton. Selesai pencucian, kertas saring yang berisi residu sampel ditempatkan dalam cawan porselin yang sudah diketahui berat konstannya dengan mengeringkan pada temperatur $105^{\circ}-110^{\circ} \mathrm{C}$. Residu sampel dioven pada temperatur $70^{\circ} \mathrm{C}$ selama 6 jam, kemudian dioven lagi pada temperatur $105^{\circ}-110^{\circ} \mathrm{C}$ selama 3 jam. Dinginkan dalam desikator selama 30 menit untuk selanjutnya ditimbang untuk mendapatkan berat konstan. Proses selanjutnya adalah pengabuan pada tanur listrik dengan temperatur $500^{\circ}-600^{\circ} \mathrm{C}$ selama 3 jam sampai pengabuan merata. Dinginkan dalam desikator selama 30 menit untuk selanjutnya ditimbang beratnya.

$$
S K(\%)=\frac{(\mathrm{c}-\mathrm{d}-\mathrm{b})}{\mathrm{A}} \times 100 \%
$$

Keterangan:

$\mathrm{a}=$ berat sampel $(\mathrm{g})$

$\mathrm{b}=$ berat kertas saring yang telah dioven $105^{\mathrm{O}}-110^{\circ} \mathrm{C}(\mathrm{g})$

$\mathrm{c}=$ berat cawan + kertas saring + residu kering dioven $105^{\mathrm{O}}-110^{\circ} \mathrm{C}(\mathrm{g})$

$\mathrm{d}=$ berat cawan + residu setelah ditanur pada temperatur $500^{\circ}-600^{\circ} \mathrm{C}(\mathrm{g})$ 


\section{Penentuan energi bruto (Gross Energi/GE)}

Bomb calorimeter, alat yang dipergunakan untuk mengukur GE dipersiapkan terlebih dahulu sesuai dengan Standar Operasional Prosedur. Sebanyak 1 g sampel dibuat menjadi pelet. Pelet dimasukkan ke dalam cawan baja yang sudah diketahui beratnya. Tabung pembakaran dipersiapkan dengan cara menghubungkan elektrode pada tutup tabung dengan kawat platina dan cawan berisi pelet ditempatkan pada posisinya. Sampel yang berbentuk pelet dihubungkan dengan kawat platina menggunakan benang dimana kedua ujung benang ditindih oleh pelet. Tabung bomb diisi aquades $1 \mathrm{ml}$, ditutup rapat, lalu ditempatkan pada posisinya pada alat bomb calorimeter. Alirkan oksigen dengan tekanan 25-30 atm.

Setelah tabung pembakaran dimasukkan ke dalam tabung penyerap panas dan terendam secara sempurna, barulah dilakukan pemasangan penutup luar tabung bomb calorimeter. Bomb calorimeter siap bekerja bila suhu yang ditunjukkan pada termometer yang terpasang pada bomb calorimeter telah konstan, dan suhu tersebut dicatat. Proses pengeboman mulai dilakukan dengan mengaktifkan tombol pengebomb dan suhu pada termometer terus dipantau. Pembacaan suhu dilakukan sete lah 3 menit pengeboman dan dilanjutkan setiap menit sampai suhu mencapai maksimal/stabil. Proses pengeboman selesai apabila suhu maksimal sudah tercapai dan sampel pada tabung bomb calorimeter menjadi abu berwarna putih keabu-abuan.

$$
G E=\frac{\mathrm{T} 1-\mathrm{T} 0}{\mathrm{~S}} x \text { bomb faktor }(k k a l / g)
$$

Keterangan:

$\mathrm{T} 1=$ suhu akhir $\left({ }^{\circ} \mathrm{C}\right)$

$\mathrm{To}=$ suhu awal $\left({ }^{\circ} \mathrm{C}\right)$

$\mathrm{S}=$ sampel $(\mathrm{g})$

Bomb factor $=$ diperoleh dari nilai rata-rata pengeboman 20 pelet asam bensoat (1g) yang mempunyai kandungan GE 6,31458 kkal

\section{Produk Fermentasi In vitro}

In vitro dilakukan pada inkubasi 24 dan 48 jam. Metode yang digunakan adalah Minson \& Mc Leod Method (1972) yang dimodifikasi. Cara kerja untuk penelitian in vitro yaitu: sampel ransum yang telah halus dimasukkan ke dalam tabung in vitro sebanyak $0,2500 \mathrm{~g}$ dan ditambah $25 \mathrm{ml}$ cairan rumen buffer McDougall dengan kondisi $40^{\circ} \mathrm{C}$, selanjutnya diinkubasikan dalam shakerbath dengan suhu $40^{\circ} \mathrm{C}$ selama $4 \mathrm{jam}$. Cara kerja yang sama dilakukan untuk inkubasi selama 48 jam. Setiap jam tabung in vitrodigoyangkan dan dikeluarkan udaranya.

Setelah lama waktu inkubasi yang ditentukan, selanjutnya dikeluarkan dan dipusingkan pada 3500 rpm selama 10 menit. Substrat akan terpisah menjadi endapan di bagian bawah dan supernatan yang bening berada di bagian atas. Supernatan dipakai untuk analisis $\mathrm{N}-\mathrm{NH}_{3}$, VFA total dan pH. Endapan digunakan untuk analisis degradasi bahan kering (BK) dan bahan organik (BO). Residu endapan dipindahkan ke dalam cawan yang telah diketahui bobot kosongnya. Diuapkan dalam forced draught oven suhu $70^{\circ} \mathrm{C}$ sampai kering \pm 12 jam dan dipindahkan ke oven bahan kering suhu $105^{\circ} \mathrm{C}$ selama 9 jam, lalu didinginkan dalam desikator kemudian ditimbang. Dilanjutkan pembakaran ke dalam tanur sampai diperoleh bobot abu. Sebagai blangko adalah residu fermentasi tanpa ransum. Kecernaan fermentatif BK dan BO ransum dapat dihitung dengan rumus:

$$
\begin{aligned}
& K C B K(\%)=\frac{B K \text { sampel }(g) D[B K \text { residu }(g) D B K \text { residu blangko }(g)]}{\text { BK sampel }(\mathrm{g})} \times 100 \% \\
& K C B O(\mathrm{~g})=\frac{B 0 \text { sampel }(g) D[B O \text { residu }(g) D B O \text { residu blangko }(g)]}{B O \text { sampel }(g)} \times 100 \%
\end{aligned}
$$

\section{Konsentrasi N-NH3dan VFA Cairan Rumen}

Kadar $\mathrm{N}-\mathrm{NH}_{3}$ ditentukan dengan metode phenolhypochlorite melalui pembacaan dengan Spectrofotometer menurut Solorzano (1969). Sebanyak $15 \mathrm{ml}$ supernatan dimasukkan ke dalam botol yang sudah berisi 5 tetes asam sulfat pekat, kemudian diencerkan 100 kali. Supernatan yang sudah diencerkan ini diambil sebanyak $5 \mathrm{ml}$, dimasukkan ke dalam tabung spektro yang sudah diisi dengan larutan standar. Kemudian ditambahkan berturut-turut 0,2 ml larutan phenol; o,2 ml larutan Natrium nitroprusside; dan $0,5 \mathrm{ml}$ larutan pengoksidasi. Pembacaan reaksi warna dilakukan 5 menit setelah penambahan larutan pengoksidasi dengan spektrofotometer.

Pengukuran kadar asam lemak atsiri (VFA) total dilakukan dengan cara penyulingan uap menurut General Laboratory Procedure (1966). Sebanyak 5 $\mathrm{ml}$ supernatan dimasukkan ke dalam tabung khusus kemudian ditambahkan $1 \mathrm{ml} \mathrm{H}_{2} \mathrm{SO}_{4}$ 15\% lalu ditutup. Tabung dihubungkan dengan labu pendingin dan labu yang berisi air lalu dipanaskan. Hasil destilasi ditampung di dalam erlenmeyer yang berisi 5 $\mathrm{ml} \mathrm{NaOH} 0,5 \mathrm{~N}$. Proses destilasi berakhir sampai destilat yang ditampung mencapai volume \pm 300 ml. Tambahkan 1-2 tetes indikator phenolptalin dan dititer dengan $\mathrm{HCl} 0,5 \mathrm{~N}$ sampai terjadi perubahan warna dari merah jambu menjadi tidak berwarna.

$$
\text { VFA Total }=(\mathrm{aĐ} \mathrm{b}) \times \mathrm{N} \mathrm{HCl} \times 1000 / 5 \mathrm{mM}
$$

$\mathrm{a}=\mathrm{ml} \mathrm{HCl}$ yang dibutuhkan untuk titrasi blanko $(5 \mathrm{ml}$ $\mathrm{NaOH})$

$\mathrm{b}=\mathrm{ml} \mathrm{HCl}$ yang dibutuhkan untuk titrasi hasil destilasi 


\section{Analisis Data}

Data yang diperoleh dianalisis menggunakan sidik ragam (Anova). Apabila terdapat hasil yang berbeda nyata $(\mathrm{P}<0,05)$ antar perlakuan, maka analisis dilanjutkan dengan uji kontras ortogonal pada taraf 5\% (Steel dan Torrie, 1995).

\section{HASIL DAN PEMBAHASAN}

\section{Kandungan Nutrisi Silase}

Setelah penyimpanan selama 21 hari, maka silase dikeringkan untuk diamati komposisi kimianya di Laboratorium Nutrisi dan Makanan Ternak Fapet. Hasilnya disajikan dalam Tabel 1.

Tabel 1 Kandungan Nutrisi Silase Batang Pisang dan Kembang Telang

\begin{tabular}{|c|c|c|c|c|c|}
\hline \multirow{2}{*}{ Parameter } & \multicolumn{4}{|c|}{ Perlakuan* } & \multirow{2}{*}{ SEM } \\
\hline & A & $\mathrm{B}$ & $\mathrm{C}$ & $\mathrm{D}$ & \\
\hline Bahan kering (\%) & $16,22 \mathrm{c}$ & $17, \mathrm{oOc}$ & $19,92 b$ & $24,87 a$ & 0,91 \\
\hline Bahan organic (\%) & $87,74 d$ & $88,89 \mathrm{c}$ & $90,75 b$ & $91,51 \mathrm{a}$ & 0,34 \\
\hline $\mathrm{bu}(\%)$ & $12,26 \mathrm{a}$ & $11,11 b$ & $9,25 \mathrm{c}$ & $8,49 d$ & 0,34 \\
\hline rotein kasar (\%) & $11,11 d$ & $12,08 \mathrm{c}$ & $14,30 b$ & $15,90 a$ & 0,49 \\
\hline Serat kasar (\%) & 21,58 & 21,22 & 21,14 & 19,00 & 0,92 \\
\hline Lemak kasar (\%) & 21,46 & 19,60 & 18,35 & 18,22 & 1,69 \\
\hline Energi (kkal/kg) & 3477,04 & 3456,72 & 3511,58 & 3763,20 & 156,30 \\
\hline \multicolumn{6}{|c|}{$\begin{array}{l}\text { Keterangan: } \\
\text { Nilai rata-rata perlakuan yang diikuti oleh hurup kecil yang sama pada baris yan } \\
\text { sama menunjukkan perbedaan yang tidak nyata }(P>0,05) \text {. } \\
\text { A: } 65 \% \text { batang pisang }+30 \% \text { pollar }+5 \% \text { (molasis }+E M 4) \\
\text { B: } 55 \% \text { batang pisang }+10 \% \text { C. ternatea }+30 \% \text { pollar }+5 \% \text { (molasis }+E M 4) \\
\text { C: } 45 \% \text { batang pisang }+20 \% \text { C. ternatea }+30 \% \text { pollar }+5 \% \text { (molasis }+ \text { EM4) } \\
\text { D: } 35 \% \text { batang pisang }+30 \% \text { C. ternatea }+30 \% \text { pollar }+5 \% \text { (molasis }+ \text { EM4) }\end{array}$} \\
\hline
\end{tabular}

Semakin banyak kandungan C. ternatea dalam silase batang pisang, maka kandungan nutrisi silase menjadi semakin meningkat. Kandungan protein kasar silase batang pisang tanpa C. ternatea (perlakuan A) adalah $11,11 \%$. Semakin meningkat kandungan C. ternatea dalam silase mengakibatkan kandungan protein kasar silase juga semakin meningkat dan tertinggi pada perlakuan D dimana kandungan protein paling tinggi yaitu $15,90 \%$. Hal ini sangat logis karena C. ternatea merupakan hijauan leguminosa sebagai sumber protein. C. ternatea adalah leguminosa yang berkualitas tinggi dan merupakan jenis kacangkacangan yang kaya akan protein, dijuluki alfalfa tropis, sering disebut pula sebagai bank protein yang dapat tumbuh dengan biaya produksi yang rendah (Cook et al. 2005).

\section{Kecernaan In vitro}

Penambahan $C$. ternatea pada silase batang pisang juga mampu meningkatkan kecernaan silase secara in vitro. Kecernaan bahan kering silase batang pisang tanpa penambahan $C$. ternatea adalah 58,25\% (Tabel 2). Penambahan C. ternatea sampai 30\% (perlakuan D) mampu meningkatkan kecernaan bahan kering danbahan organik tertinggi masing-masing $70,40 \%$ dan 73,08\% (Tabel 2). Derajatkeasaman ( $\mathrm{pH}$ ) cairan rumen untuk semua perlakuan berada pada kisaran normal yaitu 6,97- 7,20. Hasil penelitian ini sedikit lebih tinggi dibandingkan Suryani et al. (2013) yang mendapatkan $\mathrm{pH}$ cairan rumen fermentasi in vitro ransum sapi bali yang terdiri atas rumput gajah, jerami padi, gamal, kaliandra dan konsentrat adalah 6,02 -6,17.

Tabel 2 Kecernaan Silase secara In vitro

\begin{tabular}{lccccc}
\hline \multirow{2}{*}{ Parameter } & \multicolumn{5}{c}{ Perlakuan* $^{*}$ SEM } \\
\cline { 2 - 5 } & $\mathrm{A}$ & $\mathrm{B}$ & $\mathrm{C}$ & $\mathrm{D}$ & \\
\hline Kecernaan BK (\%) & $58,25 \mathrm{a}$ & $62,25 \mathrm{~b}$ & $68,64 \mathrm{c}$ & $70,40 \mathrm{c}$ & 2,70 \\
Kecernaan BO (\%) & $60,95 \mathrm{a}$ & $69,82 \mathrm{~b}$ & $71,53 \mathrm{bc}$ & $73,08 \mathrm{c}$ & 2,76 \\
pH cairan rumen & 7,20 & 6,97 & 7,09 & 7,10 & 0,67 \\
NH3 (mMol) & $5,03 \mathrm{a}$ & $6,43 \mathrm{ab}$ & $7,26 \mathrm{~b}$ & $9,44 \mathrm{c}$ & 0,42 \\
VFA Total (mMol) & 129,33 & 132,75 & 133,82 & 132,43 & 3,01 \\
\hline
\end{tabular}

Keterangan:

Nilai rata-rata perlakuan yang diikuti oleh hurup kecil yang sama pada baris yang sama menunjukkan perbedaan yang tidak nyata $(P>0,05)$.

A: $65 \%$ batang pisang $+30 \%$ pollar $+5 \%$ (molasis + EM 4 )

B: $55 \%$ batang pisang $+10 \%$ C. ternatea $+30 \%$ pollar $+5 \%$ (molasis + EM4)

C: $45 \%$ batang pisang $+20 \%$ C. ternatea $+30 \%$ pollar $+5 \%$ (molasis + EM 4 )

D: $35 \%$ batang pisang $+30 \%$ C. ternatea $+30 \%$ pollar $+5 \%$ (molasis + EM 4$)$

Amonia (NH3) produksi fermentasi secara in vitro terjadi peningkatan dengan semakin meningkatnya jumlah hijauan $C$. ternatea dalam silase (Tabel 2). Amonia merupakan hasil perombakan protein kasar di dalam rumen. Semakin meningkatnya kandungan protein silase karena penambahan C. ternatea, makakonsentrasi $\mathrm{NH}_{3}$ cairan rumen in vitro pun menjadi senakin meningkat. Konsentrasi $\mathrm{N}-\mathrm{NH}_{3}$ substrat ransum pada semua perlakuan berada pada kisaran ideal untukmendukung pertumbuhan bakteri secara optimal yaitu 4-12 mMol (Sutardi, 1979) atau 6-21 mMol (McDonald et al., 2002).

Demikian juga halnya dengan konsentrasi VFA, semakin banyak kandungan $C$. ternatea dalam silase, maka kandungan bahan organik, dan energi meningkat yang akan menghasilkan konsentrasi VFA sebagai sumber energi juga meningkat. Konsentrasi VFA total hasil penelitian ini berkisar antara 129,33 - 133,82 mMol. Konsentrasi VFA total ini sudah sesuai untuk mendukung pertumbuhan dan aktivitas mikroba dalam rumen, dimana menurut Sutardi (1995), konsentrasi VFA total yang optimal untuk mendukung pertumbuhan dan aktivitas mikroba rumen yang optimal adalah 8o-16o mMol.

\section{Komponen Serat}

Komponen serat NDF yang terdapat pada dinding sel tanaman dan biasanya menjadi penghambat kecernaan, semakin menurun dengan tingginya 
kandungan C. ternatea dalam silase (Tabel 3). Hal ini berdampak pada peningkatan kecernaan BK maupun BO silase (Tabel 2). Hal ini juga diperkuat dengan hasil ADL (komponen lignin) mengalami penurunan dengan meningkatnya $C$. ternatea. Menurunnya lignin juga mempermudah mikroba dalam rumen untuk mencerna silase sehinggan kecernaan menjadi meningkat.

Tabel 3 Komponen Serat Silase

\begin{tabular}{lccccc}
\hline \multirow{2}{*}{\multicolumn{1}{c}{ Parameter }} & \multicolumn{4}{c}{ Perlakuan } & \multirow{2}{*}{ SEM } \\
\cline { 2 - 5 } & $\mathrm{A}$ & $\mathrm{B}$ & $\mathrm{C}$ & $\mathrm{D}$ & \\
\hline NDF (\%) & $63,79 \mathrm{a}$ & $52,66 \mathrm{~b}$ & $46,7 \mathrm{Oc}$ & $31,32 \mathrm{~d}$ & 4,73 \\
ADF (\%) & $33,82 \mathrm{a}$ & $28,25 \mathrm{~b}$ & $28,06 \mathrm{~b}$ & $20,41 \mathrm{c}$ & 1,34 \\
ADL (\%) & 11,07 & 12,02 & 10,06 & 7,89 & 0,96 \\
Selulosa (\%) & $22,76 \mathrm{a}$ & $16,23 \mathrm{~b}$ & $18,00 \mathrm{~b}$ & $12,52 \mathrm{c}$ & 1,73 \\
Hemiselulosa (\%) & $29,96 \mathrm{a}$ & $24,41 \mathrm{~b}$ & $18,65 \mathrm{c}$ & $10,91 \mathrm{~d}$ & 2,07 \\
\hline
\end{tabular}

Keterangan:

Nilai rata-rata perlakuan yang diikuti oleh hurup kecil yang sama pada baris yang sama menunjukkan perbedaan yang tidak nyata $(P>0,05)$

A: $65 \%$ batang pisang $+30 \%$ pollar $+5 \%$ (molasis $+E M 4$ )

B: $55 \%$ batang pisang $+10 \%$ C. ternatea $+30 \%$ pollar $+5 \%$ (molasis + EM 4 )

C: $45 \%$ batang pisang $+20 \%$ C. ternatea $+30 \%$ pollar $+5 \%$ (molasis $+\mathrm{EM} 4$ )

D: $35 \%$ batang pisang $+30 \%$ C. ternatea $+30 \%$ pollar $+5 \%$ (molasis + EM 4 )

Densitas yang semakin tinggi pada silase yang mengandung Clitoria ternatea disebabkan karena kandungan nutrisi yang lebih padat (Tabel 1) dan lebih mudah dicerna (Tabel 2) karena bahan organik yang terdapat pada silase yang mengandung Clitoria ternatea (perlakuan B, C dan D) mempunyai persentase daya larut air yang lebih tinggi (Tabel 3).

\section{SIMPULAN DAN SARAN}

\section{Simpulan}

Kualitas silase kombinasi batang pisang dengan C. ternatea secara kimiawi mengandung nutrisi yang semakin meningkat dengan meningkatnya kandungan C. ternatea di dalam silase, khususnya kandungan bahan organik, protein kasar dan energi. Produk fermentasi in vitro, seperti $\mathrm{pH}, \mathrm{NH}_{3}$ dan VFA total hasilnya memenuhi kriteria untuk pertumbuhan dan aktivitas mikroba rumen secara optimal. Kecernaan bahan kering dan bahan organik secara in vitro juga menunjukkan peningkatan dengan meningkatnya kandungan C. ternatea di dalam silase.

\section{Saran}

Pemberian batang pisang sebagai pakan ternak sebaiknya dilakukan dengan pembuatan silase dengan menambahkan hijauan C. ternatea dan molasis yang sudah mengandung EM4. Hal ini dikarenakan melalui pembuatan silase dengan C. ternatea akan mampu meningkatkan kandungan nutrisi silase batang pisang sehingga produktivitas ternak meningkat karena kebutuhan nutrisinya terpenuhi.

\section{UCAPAN TERIMAKASIH}

Peneliti mengucapkan terimakasih kepada Kementerian Riset Teknologi dan Pendidikan Tinggi, Rektor Universitas Udayana, dan Lembaga Penelitian dan Pengabdian kepada Masyarakat atas ijin dan pendanaan riset melalui dana DIPA PNBP Universitas Udayana Tahun anggaran 2019 Sesuai dengan Surat Perjanjian Penugasan Pelaksanaan Penelitian No: 551-103/UN14.4.A/LT/2019, tanggal: 10 April 2019. Peneliti juga mengucapkan terimakasih kepada mahasiswa Fapet Unud yang telah membantu pelaksanaan penelitian ini sehingga dapat terlaksana dengan baik.

\section{DAFTAR PUSTAKA}

A.O.A.C., 2005. Official methods of analysis, Association of Official Analytical Chemists, Edn, 17th., Washington D.C.

Cook, B. G., B. C. Pengelly, S. D. Brown, J. L. Donnelly, D. A. Eagles, M. A. Franco, J. Hanson, B. F. Mullen, I. J. Partridge, M. Peters, Schultze-Kraft R. 2005. Tropical forages. Brisbane (Australia): CSIRO, DPI\&F (QId), CIAT and ILRI.

Dhalika, T., A. Budiman dan Mansyur. 2015. Kualitas Silase Rumput Benggala (Panicum maximum) pada Berbagai Taraf Penambahan Bahan Aditif Ekstrak Cairan Asam Laktat Produk Fermentasi Anaerob Batang Pisang. Jurnal Peternakan Indonesia. 17(1): 77-82.

General Laboratory Procedures. 1966. Departement of Dairy Science. University of Wisconsin. Madison.

McDonald, P., R. A. Edwards, J. F. D. Greenhalgh, and C. A. Morgan. 2002. Animal Nutrition. 6th Ed. Pretice all, London.

Minson, D. J. and M. N. Mc Leod. 1972. The In Vitro Technique. Its modification for estimating digestibility of large numbers of tropical pasture sample. Divisi on of Tropical Pasture Technical Paper. No. 8 Common Wealth Scientific and Industrial Research Organization Australia

Nuryanti, L. dan B. Waryanto. 2016. Outlook Komoditas Pisang. Pusat Data dan Sistem Informasi Pertanian Kementerian Pertanian.

Rochana, A., T. Dhalika, A. Budiman dan K. A. Kamil. 2017. Nutritional Value of a Banana Stem (Musa paradisiaca Val) of Anaerobic Fermentation roduct Supplemented With Nitrogen, Sulphur and Phosphorus Sources. Pakistan Journal Nutrition. DOI: 10.3923/pjn.2017.738.742. 16 (10): 738-742.

Solorzano, L. 1969. Determination of ammonia in natural waters by the phenol hypochlorite method. Limnology and Oceanography. Vol. 14 
(5): 799-801. American Society of Limnology and Oceanography.

Steel, R. G. D. and J. H. Torrie. 1995. Priciples and Procedures of Statistic. McGraw-Hill Book Co. Inc., New york.

Suryani, N. N., I K.M. Budiasa, dan I P. A. Astawa. 2013. Suplementasi gamal sebagai rumen degradable protein (RDP) untuk meningkatkan kecernaan in-vitro ransum ternak ruminansia yang mengandung jerami padi. Majalah Ilmiah Petrnakan. 16 (1): 1 - 5 .

Sutardi, T. 1979. Ketahanan protein bahan makanan terhadap degradasi oleh mikroba rumen dan manfaatnya bagi peningkatan produktivitas ternak. Pros. Seminar Penelitian Penunjang Peternakan, LPP. Bogor.

Wina, E. 2011. Tanaman pisang sebagai pakan ternak ruminansia. Jurnal Wartazoa. 11 (1): 20-27 